\title{
技術資料
}

供用下における鋼橋の補修・補強溶接*

堀 川浩 甫**, 高 橋 芳 樹***

\section{Repairing and Strengthing Existent Steel Bridges by Welding under Service for Traffic**}

\author{
by Kohsuke Horikawa ${ }^{* *}$ and Yoshiki Takahashi*** \\ キーワード：補修溶接，現場溶接，鋼橋，疲労損傷
}

\section{1.はじめに}

社会資本の実質的な整備は,昭和 30 年代以降の高度経 済成長期に始まり, 道路橋の施工も昭和 39 年のオリン ピック等の大型事業に向け年々增大していった。橋梁に ついてみると, 昭和 36 年から昭和 60 年の 25 年間に鋼橋 だけでも実に 2 万橋近い施工が行われている，その間に 交通量の増加，車両重量の増大は著しく，橋梁は苛酷な 使用状態に㧍かれている。この高度経済成長期に架けら れた多くの橋の中には十分な維持・管理が行われていた とはいいがたいものもあり，劣化が早く補修・補強を必 要とする橋梁も多く見受けられるようになったば).

最近の鋼橋の損傷のひとつは疲労椇甥で, プレート ガーダーの主桁と, 対傾構, 横桁, 横構などとの接合部, ソールプレートのすみ肉溶接部, 鋼床版デッキプレート と横リブ，垂直スティフナなどとの溶接部に見られ，主 構造部材というより，今までは計算対象外とされていた 二次部材に応力集中, 面外変形, 二次応力などの影響が 重複して発生している。

疲労損傷の他に, 漏水や土砂の堆積で下フランジなど が腐食し，断面欠損をおこしている場合がある。また， 損傷ではないが橋梁の昖幅や補強を目的に垂直スティフ ナやブラケット等を既設桁に取り付ける工事もあちこち で行われるようになってきた。これらの補修や補強工事 は交通障害や交通渋滞を避けるため交通規制やステージ

\footnotetext{
*原稿受付 平成 2 年 8 月 1 日

**正員大阪大学溶接工学研究所 Member, Welding Research Institute, Osaka University 横河工事(利利根工場 Yokogawa Construction Co., Ltd. Tone Factory
}

ングを設置しないで施工しなければならない場合も多 い.したがって交通供用下で振動を受けながら，かつ作 用力の高い応力状態で施工しなければならない，そこで 本文では交通供用下で溶接補強を行う場合の問題点を整 理し，今まで行ってきた $2 \sim 3$ の実験と施工例を概説す る.

\section{2. 交通供用下での溶接上の問題点}

これまで交通供用下で橋梁の補修や補強を行うのは溶 接をさけ高力ボルトで施工するか，あるいは溶接で行う としても支承部附近であればジャッキで仮受けし，桁ス パン内であればステージングを設置して溶接部の作用応 力や振動を軽減するか，あるいは小さくなるような処置 を行って施工してきた。しかし最近では，構造上の制約 や作業スペースが狭险なことから高力ボルト施工が困難 だったり，交通障害や地理的条件からステージングが設 置できず，交通供用下で振動を受けながら溶接作業をす ることが頻繁に行われるようになってきた"-6).

供用下における既設橋梁の溶接施工上の問題点として は次のとおりである。

1) 通過車両による変動荷重で複雑な振動が生じて, 溶接施工に悪影響を及ほす。

2）溶接熱により溶接時に構造物の剛性や強度が減少 し，一時的に断面欠損状態となる。

3) 溶接収縮により座届や過度の変形が生ずる恐れが ある。

4) 補修作業は狭湓な場所が多く，さらに作業環境が 劣悪の場合が多い。

5) 補修工事は高い技術力が必要なわりに予算が少な い. 
したがって実施工にあたっては，これらの問題を十分 に配慮して施工する必要がある。

このような鋼橋の補修・補強の問題は日本だけに限ら れたことでなく，1982 年に IABSEがローザンヌにおい て“Fatigue of steel and concrete structures”と題する コロキュームをワシントンにおいてばMaintenance, Repair and Rehabilitation of Bridges"と題するシンポ ジウムが開催されている7-91.日本におけるこれらの問題 の研究として，橋梁の振動下における溶接施工について は阪神高速道路公団等による広範囲な研究が行わ $れ^{10,11)}$ ，相対的変位のない振動下における溶接はアン ダーカット等外観上の問題はあるものの, 2 3の注意を 払えぱ十分溶接は可能であるとされ，実施工においても 大きな問題はなく施工されている，2)，3)の溶接熱や収 縮, 変形に対する実験, 研究も堀川等によって行われ, きちんとした管理と検討を加えて施工すれば大きな問題 を秘めながらも供用下の補修溶接は可能であり, 実施工 も各工事ごとに十分検討されて行われている，4)の作業 環境の問題は既設構造物を対象とした施工であり, ある 程度はやむを得ない面もあるが, 現地状況を十分調查把 握し，その現場にマッチした設計および施工計画をたて ることが重要である.これを怠ると設計どおりの施工が 不可能であったり，可能であっても精度の悪い施工にな る恐れがある５)の補修工事の予算については今までは ともすれば簡単に考えられ，高い技術力と旋しい施工条 件であるにもかかわらず十分な予算が得られない工事が 多かった. 少ない予算は施工管理や施工者のレベルを落 とす恐れがあり，適正な工事費の積算が望まれる。

これらの問題や研究を踏まえて, 日本鋼構造協会では “供用下にある鋼構造物の溶接による補強・補修指針” を作成し，平成 2 年 6 月には第 1 回鋼構造物の補修・補 強技街報告会が開催され, 橋梁における補修と補強の必 要性と重要性の認識を高めている ${ }^{16)}$.

\section{3. 実験例亡補修例}

ここでは, 溶接補修として多く行われている垂直ス ティフナやブラケットの取り付けが，主桁にどのような 影響を及济すか実験を行ったのでその結果と，溶接補修 のうちの代表的な例として主析と対傾構接合部の補修例 をそして特殊な例として桁中央部の下フランジを切り 取って付けかえた施工例について報告する。

1) 垂直スティフナの溶接が桁に及ぼす影響 ${ }^{12)}$

試験体は，図 1 に示すような箱断面でこの片側のウエ ブに垂直スティフナを取付け溶接する。載荷は 3 点曲げ で行い, 上, 下フランジの応力を許容応力 $(\sigma=1400 \mathrm{kgf} /$ $\left.\mathrm{cm}^{2}\right)$ まで高めて被覆アーク溶接で施工した。溶接中にた わみ変化を測定した結果を図 2 に示す。これによれば, 溶接中はたわみを増すがその量はわずかで，最大でも $0.25 \mathrm{~mm}$ 程度である.溶接が終了すると回復し，わずか
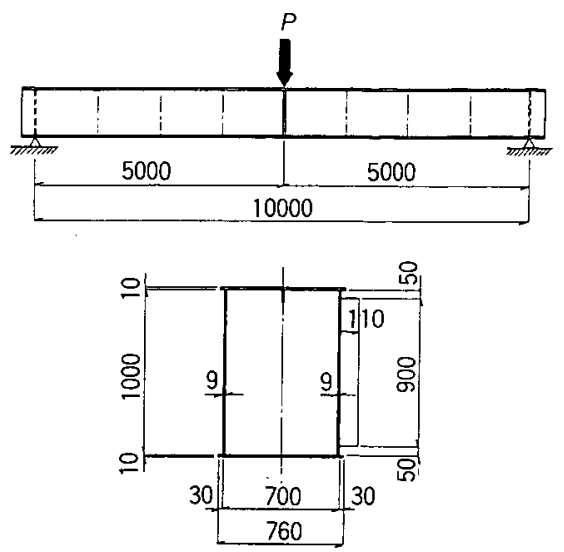

図 1 試験体寸法

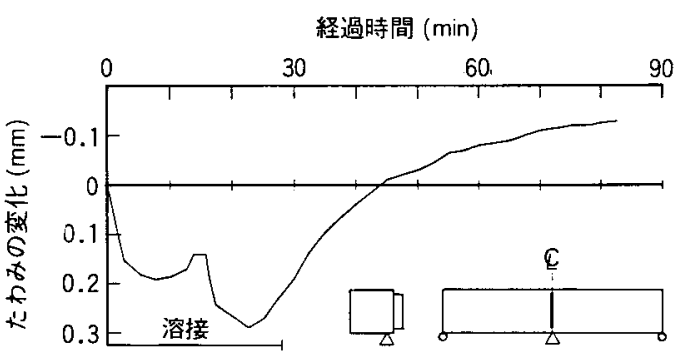

図 2 たわみの変化

経過時間 (min)

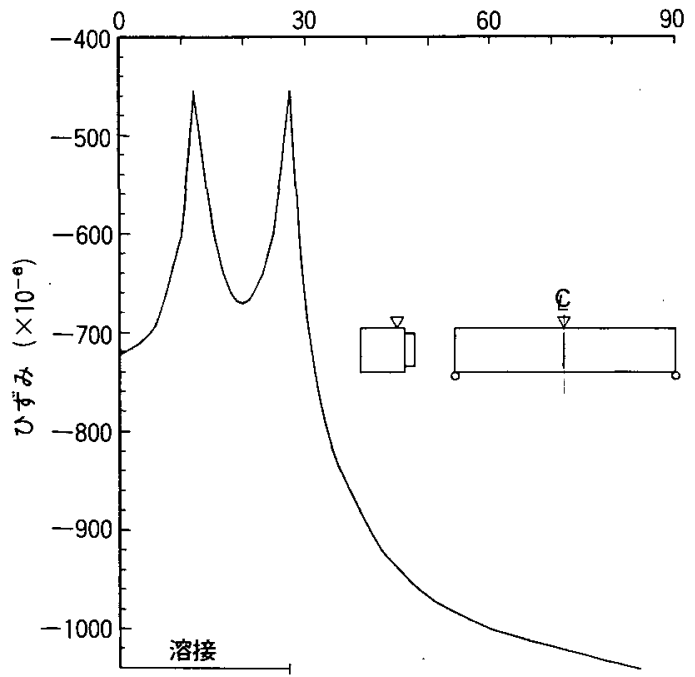

图 3 上フランジのひずみの変化 
であるが逆方向のたわみが残る。図 3 に桁の上フランジ のひずみの溶接開始からの経時変化を示す．これによれ ば，压縮側上フランジのひずみは溶接中は隇少し，溶接 後は逆に急激に增加する，以上のことから箱析に垂直ス ティフナを溶接する場合は溶接部付近が熱影響と収縮に より局部的に大きなひずみが発生するが，たわみは小さ く, 忘力の再配分が行われ，局部的な弱点を作る可能性 はあるものの，施工上は大きな問題にならないと考えら れる.

\section{2) ブラケットの溶接が析に及ぼす影響 ${ }^{12)}$}

試験体は，1)の垂直スティフ十取り付けの場合と同様 で, 支間中央にフランジの応力が許容応力度 $(\sigma=1400$ $\left.\mathrm{kgf} / \mathrm{cm}^{2}\right)$ となるように集中荷重を載荷し，図 4 に示すよ うな順序で被覆アーク溶接で施工した。箱桁の断面寸法 は図1に示したものと同じであるが,ブラケットには上， 下フランジがあり，この部分は完全溶込みなので溶接量 は垂直スティフナに比べて多い，図 5 に溶接時間とたわ みの関係を示す、桁のたわみは溶接の進行と共に増加し， 支間中央で最大 $0.9 \mathrm{~mm}$ の增加となったが，溶接終了後 は減少し，支間中央で $0.4 \mathrm{~mm}$ となった。こ机は温度上 昇, 温度差により生じたたわみの増加が, 溶接終了後に は収縮により減少したものと考えられる，たわみの最大 値が垂直スティフナの溶接の場合より大きいのは，溶接 量が多いため温度上昇や溶接収縮の影響が大きいためで ある.ひずみの変化は図 6,7 に示すように,ブラケットの フランジ溶接中は桁の上フランジのひずみは滅少し，下

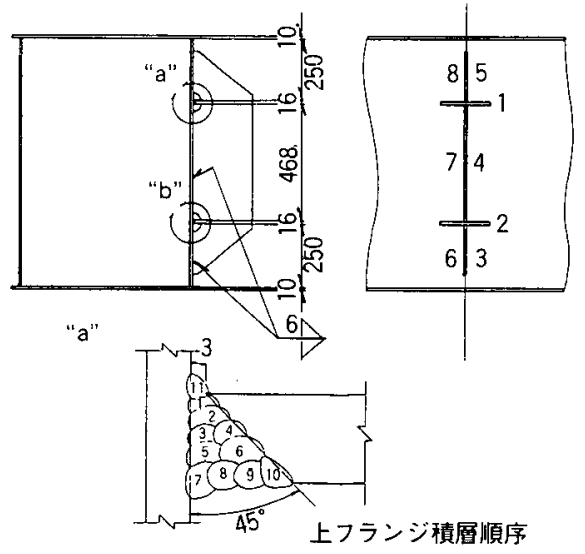

"b"

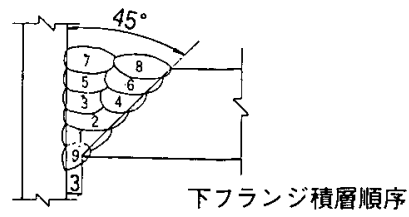

図 4 ブラケットの取り付け及び溶接順序
フランジのひずみは増加する．ウエブおよびリブの溶接 中および溶接後流，上フランジのひずみは大幅の增加と なり，塑性ひずみ域まで達し，下フランジのひずみは初 期状態よりわずかであるが減少している。これは，桁の 上フランジは荷重による圧縮ひずみに溶接収縮による圧 縮ひずみが加えられたためであり，下フランジは荷重に よる引張ひずみに溶接収縮による圧縮ひずみが加わった ためである。

以上のことから，許容応力に近い曲げ忍力が作用する 箱桁へ溶接でブラケットを取り付ける場合, 溶接中は引 張側フランジが，最終状態では圧縮側フランジが危険な 状態となる可能性がある。しかし，このひずみは局部的 なものと考えられ，たわみの変化も少ないことから，垂

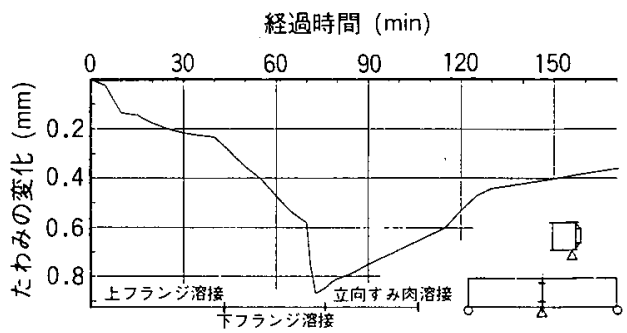

図 5 たわみの変化（中央ブラケット溶接時）

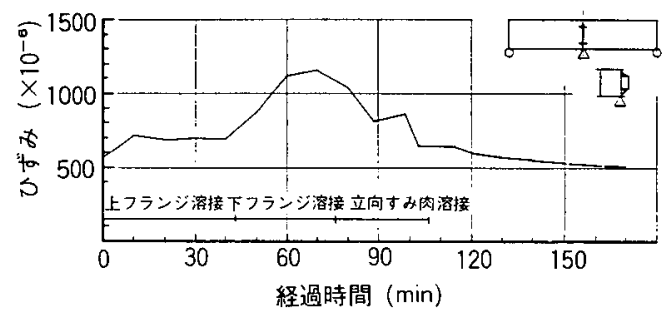

图 6 下フランジのひずみの変化（中央ブラケット 溶接時)

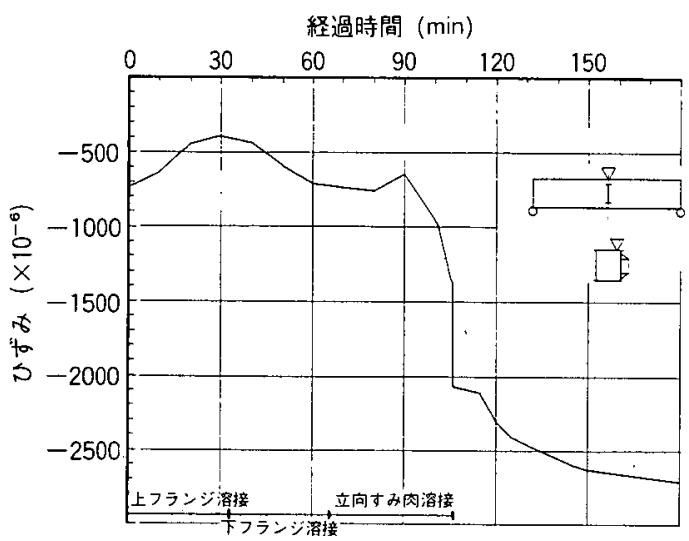

图 7 上フランジのひずみの変化（中央ブラケット 溶接時) 
直スティフナの場合と同様に溶接施工上は特に大きな問 題となることはないと考えられる。この結果を踏まえて， 奏施工では施工に影響のない範囲まで開先角度を小さく して溶接量な少なくし，溶接順序も上フランジと下フラ ンジを交互に溶接するなど温度上昇を極力わさえる配慮 を行って問題なく施工している.

3) 主析と対傾構接合部の補修溶接

主桁と対傾構の取り合い部に発生している疲労損傷 は，床版のたわみにより主桁に生じる倒れを対傾構が拘 束し，これにより上フランジ近傍に首振り現象を起こす のが主な原因であろうと言われている ${ }^{13)}$ 。この損傷事例 が報告されている橋梁は昭和 30 年後半から 40 年代に製 作, 架設された橋梁が多く, 床版の支間長は $3.8 \mathrm{~m}$ 程度と 大きく，床版厚は $18 \mathrm{~cm}$ と薄い設計となっており，現在 の示方書の規定（例えば支間長 $3.8 \mathrm{~m}$ のとき休版厚 26.2 $\mathrm{cm})$ と比べると剛性の之しい構造となっている。これら の多くは，現在縦桁増設等の床版補強が行われている。 主桁と対傾構接合部には床版補強の前か後かは不明であ るが，現在も再塗装時の調查や日常点検の折に損傷が発 見されている，疲労亀裂の発生位置は，すみ肉溶接部の トウ部から発生するものが多いが，中にはルート部から の亀裂やスカラップ側からの刍裂，それにウエブやり ベット孔などからも発生している。 そして，損傷は 1 個 ではなく複数であったり，垂直スティフナ前面からスカ ラップまで板厚貫通している大きな損傷もある。これら の中には大型車両通過時に亀裂が脈打っていることが目 視で確認できるものもある。図 8 に対傾構接合部の損傷
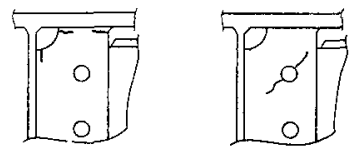

トウ部のきれつ リベット部のきれつウエブのきれつ

図 8 プレートガーダーにおける疲労椇傷例 位置例を示す.

亀裂が貫通している場合の補修要領を以下に，そして 図 9 には補修順序を示す.

(1)亀裂部近辺の塗装をすべて除去し，浸透探傷検查ある

いは磁粉探傷検查により亀裂状況を確認する。

(2)垂直スティフナのA 面溶接部を染さ $2 \mathrm{~mm}$ 程度ガウ ジングした後, 亀裂部が相対変位を起こさないように 仮付け溶接する。

(3) B 面の亀裂部を全長にわたり垂直スティフナ板厚の

$1 / 2$ 程度までガウジングする.

(4)グラインダーで開先整形したのち低水素系溶接棒で溶

接する。

(5)最初に行った仮付け溶接を含めて A 面を溶接ビード 全長にわたり未溶接部を完全に除去するまでガウジン グする。

(6)(4)と同様,グラインダーで開先整形したのち低水素系 溶接棒で溶接する。溶接は完全溶込み溶接とし, 溶接 ビードの脚長は $8 \mathrm{~mm}$ とする。

(7)溶接止端部をグラインダーで滑らかに仕上げるか，あ るいはティグ処理で溶接止端部を滑らかにする。

(8)溶接終了後，浸透探傷試験あるいは磁粉探傷試験で損

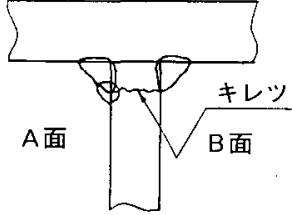

(1)A面の一部ガウジング後 仮付溶接

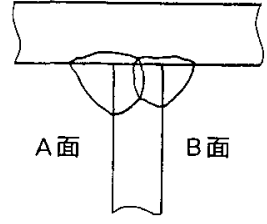

(2) B面側からキレツ部を ウエブ厚の1/2程度 ガウジング後溶接

(3) A面側から仮付を含め キレツ部の残りをガウジ ング後溶接

图 9 補 修 順 序

傷のないことを確認する。

交通供用下で溶接をする場合，溶接部ができるだけ相 対変位を起こさないようにし，また同じような損傷が再 び生じないよう，すみ肉溶接から完全溶込み溶接とする のがよい，さらに疲労強度を高めるためグラインダーお よびティグ処理で止端部を滑らかにする等の配慮が必要 である。
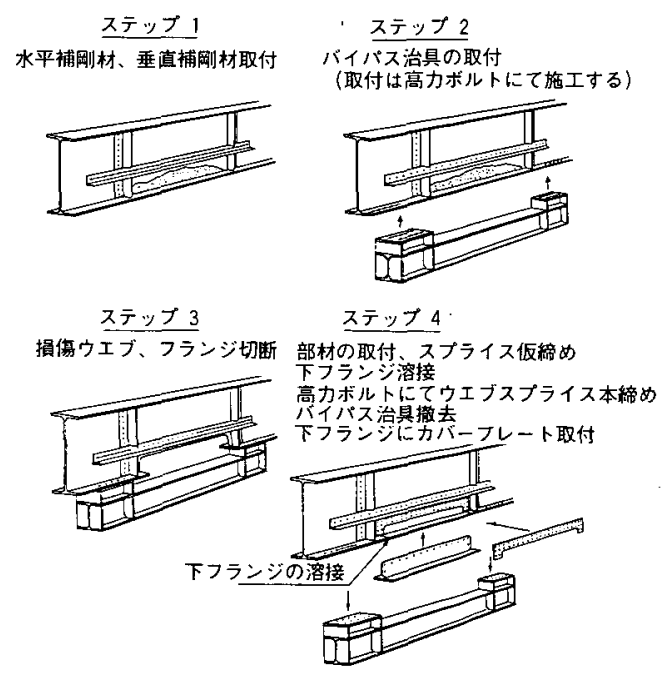

図 10 補修順序 


\section{4) 桁の改造}

鋼橋の損偒原因の一つに腐食による損傷がある，腐食 の生じやすい個所は，橋脚まわりの支承部や伸縮継手近 傍であるが，中には支間中央に近い場所て腐食していた 例もある。腐食による損傷は板厚が減少する場合が多く， 極端な場合は下フランジ上に土砂が堆積し，下フランジ やウエブに穴があくほど腐食していることもある。

このような析の補修方法はいろいろ考元られたが，こ こでは桁中央部の下フランジおよびウエプの腐食部分を 切断除去し，新規に T 形材を溶接と高力ボルトを併用し て取り付けた施工例を示す。本工事の施工場所は下が交 通の激しい交差点であり，ステージングの設置が不可能 なこと，腐食の程度が大きいことから，仮継ぎ材により 力の迂回路を設けるバイパス工法で施工することにし た.

施工方法を以下に，補修要領を図 10 に示す。

(1)損傷部近辺に堅固な足場を設置する.

(2)補修部に水平扔よび垂直スティフナを高力ボルトで取 り付ける。

(3)下フランジを孔明けし，バイパス材を高力ボルトで取 り付ける。

(4)損傷したウエブ, フランジをがス切断する. (5)新規部材を取り付け，ウエブの高力ボルトを仮締する。

(6)下フランジを裏波溶接で施工する，したがってウエブ の一部にスカラップを設け，ウエブをはさんで溶接工 2 人のリレーパス方式で施工する。

(7)ウエブスプライスプレートを本締めしたのち, バイパ ス材を撤去する。

(8)下フランジにカバープレートを取り付ける.

本工事では, ウエブおよび下フランジ切断時にバイパ ス材を設け，応力を伝達するという特殊な工法を用いた 溶接補修を行っており,これまで施工が困難と思われて いた補修も可能となった例である14).

\section{4.あとがき}

本文では，供用下に㧈ける鋼橋の補修・補強溶接の実 験例と比較的多い補修例を概説したが, 最近ではこの他 にも様々な損傷が溶接で補修されるようになり，補修．
補強技術も高まっている。しかし，溶接による補修研究 はまだ第一歩を踏み出したところであり，まだまだ解明 しなければならない問題も多く，安易に施工すれば大事 故にもつながる恐れがある。また，補修箇所の条件によっ ては既往の研究成果をそのまま利用できないこともあ り，損賃原因とその施工方法を十分検討し，対策を講じ て施工する必要がある。

\section{参考文 献}

1）堀川；橋梁の損傷と補修，溶接構造の損傷とその 防止 II-3，溶接学会誌，Vol. 52, No. 7, 1983 年 9 月

2）補修と補強特集；橋梁と基礎<創刊 200 号記 念 $>$, Vol. 17, No. 8,1983 年 8 月

3）中井他；都市内高速道路の疲労損傷 橋梁と基 礎，1990 年 2 月

4) 徳沢他; 応力作用下にある梁への溶接, 土木学会 第 35 回年次学術講演会講演概要集, I-115, 1981 年 9 月

5）鈴木他：応力作用下で溶接された継手の機械的性 質および残留応力, 土木学会論文集 No. $362 / \mathrm{I}-4$, 1985 年 10 月

6）田中他；供用中の橋梁への補修・補強溶接 橋梁 と基礎, Vol. 19, No. 3, 1985 年 3 月

7) IABSE Reports 37; Fatigue of steel and concrete structures, IABSE Colloquium Lausanne 1982, Proceedings.

8) Ibid. 38; Maintenance, repair and rehabilitation of bridges, IABSE Symposium Washington D. C. 1982, Introductory Reports.

9) J. W. Fisher; Fatigue and Fracture in Steel Bridges - - Case Studies--, 1984

10）阪神高速道路公団：「補修・補強現場溶接施工便 覽」1982 年 5 月

11）阪神高速道路公団；「道路構造物の補修標準・鋼 構造物編」1984 年 4 月

12）浅野他；首都高速道路 4 号線床版補強工事の設 計・施工 横河橋梁技報, No. 18, 1984 年 11 月

13）岩崎他；鋼橋の疲労損偒事例と補修・補強対策 横河橋梁技報, No. 18, 1989 年 1 月

14）堀川他：荷重作用下にあるプレートガーダーの改 造に関する実験, 橋梁と基礎, Vol. 20, No. 4, 1986 年 4 月

15）堀川他；荷重作用下にあるプレートガーダーへの 溶接, 土木学会論文集 No. $368 / \mathrm{I}-5,1986$ 年 4 月

16）日本鋼構造協会；供用下にある鋼構造物の溶接に 上る補強・補修指針（案）昭和 63 年 2 月 